\title{
Becoming a refugee. A life-course approach to migration under duress
}

\section{Anja Weiß*}

\begin{abstract}
This article offers a sociological approach to the ongoing debate about the distinction between refugees and migrants. It adopts a life-course perspective on seeking refuge. Seeking refuge is embedded not only in the legal regimes of refugee protection, but also in other institutional frameworks governing the life-course. Exploring continuities between migrants and refugees allows for a better understanding of whether and under what preconditions the refugee category is applied by administrations and accessed by refugees themselves. With the help of case studies selected strategically from a larger sample of narrative interviews with university educated migrants to Germany, Turkey, and Canada, the article shows how the implementation and administration of the Geneva Refugee Convention in Germany is organized in a manner that often diverges from the empirical reality of fleeing from persecution and lack of protection. On this basis, a broader comparison with migrants in Turkey and Canada who could fall under the Geneva Refugee Convention, but who mostly refrain from claiming asylum, shows that those with better resources and socio-spatial autonomy can, if well informed, find alternative options for gaining protection rather than claiming refugee status. Whether migrants under duress see themselves as refugees and whether they claim asylum does not only result from the persecution they face but also from specificities of legal and administrative frameworks, as well as their position in global structural inequalities and it is related to divergent degrees of socio-spatial autonomy.
\end{abstract}

Keywords: Refugee status, Forced migration, Sociology of migration, Life course, Socio-spatial autonomy.

* Universität Duisburg-Essen, Duisburg, Germany. 


\section{Convertirse en refugiado. Un enfoque de curso de vida a la migración bajo coacción}

\section{Resumen}

Este artículo presenta un enfoque sociológico para el debate en curso sobre la distinción entre refugiados y migrantes. Para ello, yo adopto enfoque de curso de vida para el análisis de la búsqueda de refugio. La búsqueda de refugio está incorporada no sólo en los regímenes legales de protección a los refugiados, sino también en otras estructuras institucionales que dirigen el curso de la vida. Explorar las continuidades entre migrantes y refugiados permite una mejor comprensión de si, y bajo qué requisitos previos la categoría de refugiado es aplicada por las autoridades y accedida por los propios refugiados. Haciendo uso de estudios de caso elegidos estratégicamente a partir de una muestra mayor de entrevistas narrativas con migrantes con formación académica, en Alemania, Turquía y Canadá, el artículo muestra cómo la implementación y la administración de la Convención de Ginebra sobre los refugiados en Alemania se organiza de una forma que muchas veces se aleja de la realidad empírica de la fuga por persecución y por falta de protección. A partir de ello, se hace una comparación más amplia, con migrantes en Turquía y Canadá que podrían encuadrarse en la Convención de Ginebra sobre los refugiados, pero que, en su mayor parte, se abstienen de reivindicar asilo. Se ha observado que aquellos con mejores recursos y autonomía socio-espacial pueden, si están bien informados, encontrar alternativas para ganar protección, en lugar de reclamar el estatus de refugiado. Si los migrantes bajo coacción se ven a sí mismos como refugiados y si reclaman asilo o no es resultado no solo de la persecución que enfrentan, sino también de las especificidades de los marcos legales y administrativos, así como su posición en las desigualdades estructurales globales y, además, tiene relación con los distintos grados de autonomía socio-espacial.

Palabras clave: Estatus de refugiado, Migración forzada, Sociología de la migración, Enfoque del curso de vida, Autonomía socio-espacial. 


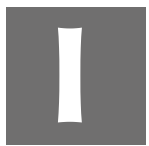
nternational law and most national migration policies differentiate clearly between migrants and refugees. While migrants can be turned away at a state's border depending on that state's interests (Money; Lockhart, 2017), refugees must receive protection, at least temporarily. This principle of non-refoulement was established by the Geneva Refugee Convention in 1951 and it is one of very few binding principles in international law governing any kind of migration (Hollifield, 2000).

While the principle of refugee protection is widely acknowledged, its implementation remains highly contested. In an era of free commerce and travel, nation states find it hard to control borders (Castles, 2007; 2017). Viewed from the perspective of policy makers, the need to protect refugees adds one more difficulty to border control. The European Union has, for example, exterritorialized border controls (Tsianos; Karakayali, 2010; Laube; Müller, 2015) which prevents most refugees from reaching EU shores and delegates the responsibility to protect refugees to countries outside Europe. Publics in receiving countries contest the truth of refugees' asylum claims which results in the continued traumatization of this very vulnerable group (Sibum, 2010).

Against this background, UNHCR takes a clear stance against confusing migrants and refugees: "Firstly, refugees are not migrants. Secondly it is dangerous, and detrimental to refugee protection, to confuse the two groups, terminologically or otherwise" (Feller, 2005, p. 27). ${ }^{1}$ This assertion is perfectly understandable in political terms, but it argues against a core process in the social sciences, that is, against revisiting categories and assessing the potential of new ones (Koser; Martin, 2011). In the contested field of refugee protection, political and conceptual concerns entangle (Van Hear, 2012). Public discourse utilizes scientific categories, and new approaches to study refugees can and have been subverted by public and political

1 See e.g. <http://www.unhcr.org/news/latest/2016/7/55df0e556/unhcr-viewpoint-refugeemigrant-right.html $>$. 
discourse, thereby undermining the already low degree of protection that has been achieved (Van Hear, 2012; Baldwin-Edwards et al., 2018; Crawley; Skleparis, 2018).

Social and political scientists acknowledge this well-known risk, but continue to espouse conceptual changes. Terms such as "forced migration", "crisis migration" or "mixed migration" respond to a growing unease within the research community about the risk that research focusing on refugees alone may exclude populations who are in similar circumstances, but without adequate protection. Expanding the scope of research to "forced migration", for example, enables researchers to include internally displaced people in their analyses (Fiddian-Qasmiyeh et al., 2014; Zetter, 2015), even though internal displacement is clearly not covered by the Geneva Convention. Another reason to explore new categories can be an insistence on the autonomy of social scientific inquiry from legal categories and policy making. The umbrella term "forced migration" also hints at the possibility that the sociology of migration could contribute insights to refugee studies (FitzGerald; Arar, 2018; Stepputat; Sørensen, 2014).

Other terms were invented based on similar considerations. The term "crisis migration" underlines that climate change may displace people on a scale similar to that of civil war. Since "crisis migration" is not governed by international accords yet, the theoretical debate referencing this term need not shy away from exploring the relation of hazards and socio-economic poverty. McAdam (2014), e.g., argues that "natural" hazards turn into crises only for individuals and communities that are socio-economically vulnerable. In a similar vein, the "mixed migration" literature argues that refugees are often forced to work and/or use the migration industry catering to labor migrants, in order to eventually reach a safe haven (Van Hear, 2009). Given the mixed nature of migration streams, policy makers targeting the (illegal) migration industry also make it harder for refugees to reach protection (Koser; Martin, 2011). 
While UNHCR fears that new categories undermine refugee protection, many researchers fear that counterfactual legal distinctions can be politically exploited to discredit refugees and essentially turn them into liars. Whether migration is "forced" by persecution or disaster or "voluntary" in search of a better life is an important dichotomous distinction for policy makers. But, as Erdal and Oeppen (2018) argue, the distinction is difficult to uphold both conceptually and empirically (Stepputat; Sørensen, 2014). There are, of course extreme cases of refugees leaving at a moment's notice and directly reaching another country in which they apply for asylum, but more often the loss of protection is gradual, refugees leave after a critical tipping point and it takes them a long time and multiple steps before they end up in protracted refugee situations or do succeed in reaching a safe haven (Koser; Martin, 2011). Forced migrants who for various reasons cannot apply for asylum must use other legal categories and are then falsely seen to have migrated "voluntarily" (Erdal; Oeppen, 2018). If empirical observations point towards complex continua and "status-making" (Robertson, 2018), defending clear-cut dichotomies may play into the hands of those who want to discredit refugees in the first place.

These conceptual debates are enlightening, but they remain within the community of scholars focusing on refugees and "forced" migration. Migration scholarship in general has largely heeded Feller's (2005) advice and shied away from exploring conceptual and empirical continuities between migration sociology and refugee studies (as exceptions see: Stepputat; Sørensen, 2014; FitzGerald; Arar, 2018). This article argues that "decentering" refugees and placing them in a general framework of migration scholarship can enable us to better understand the ways in which the refugee category is accessed and ascribed. The next section will introduce a life-course approach to migration and highlight its implications for the study of refugees. Exploring the continuities alongside the distinguishing differences between migrants and refugees enables us to use a large sample of narrative interviews with university educated migrants to Germany, 
Turkey, and Canada to contextualize case studies of migrants who have experienced violent persecution (part 2). In order to avoid the abovementioned conceptual debates, we use the term "migrants under duress" for migrants in our sample, who experienced both violence and a loss of protection by their home state, but who may not be "refugees" in the legal sense of the term in all cases.

Comparative case studies of these migrants under duress confirm that the category of "refugee" is shaped by legal and administrative regimes following hidden agendas of protecting few refugees and excluding most of them (part 3). Against this background, we then highlight cases of migrants who shied away from using the refugee category even though they did experience violent persecution and a loss of protection (part 4). These cases can best be explained with a migration sociological framework, i.e. by accepting that the processes of becoming a refugee and the need of living and/or resuming a life interact and intertwine. Whether migrants under duress claim asylum and/or receive protection depends on legal distinctions but also is an outcome of global structural inequalities and differing degrees of socio-spatial autonomy (part 5).

\section{Migration studies and the institutions governing life-courses}

Conceptual debate in migration studies is somewhat similar to the debate about refugees in that it explores options for conceptual expansion, e.g. by integrating migration in the more general sociological debate (Dahinden, 2016; Nieswand, 2016). In a sociological approach to global inequalities, Weiß $(2017 ;$ 2018) builds on Amartya Sen's capability approach (1985) to argue that all humans - migrants and non-migrants alike - strive to improve

${ }^{2}$ This term is used for the empirical study only. We do not suggest using this term in conceptual debates. Nor do we want to negate the extreme differences between e.g. a Syrian fleeing from Aleppo and an Australian choosing to study in Germany. But since the category of "refugee" is already tainted by politicians contesting refugees" truth claims, social scientists should do their job and contribute to the debate on the basis of clearly defined concepts, by a critical reflection of categories and through empirical findings (Bourdieu et al., 1991). 
their life chances. Capabilities do not only depend on the resources a person holds, but these resources must also be recognized and put to use in order to enhance capabilities. Thus, context relations matter for the validation of resources.

Highlighting context relations in the study of capabilities is relevant for the study of migration. If context relations are decisive for the transformation of resources into capabilities, people who are situated in well-endowed contexts or who can choose between contexts are in a better position than those who are in a bad place and have to stay there. Weiß (2017) calls access to superior context relations "socio-spatial autonomy". A low degree of socio-spatial autonomy would for example, be seen in a wealthy and educated person who remains fixed to a context that offers little in terms of infrastructure. It would be difficult for an IT-professional to work while her/his city is bombed; and even doctors - who are generally seen as being needed everywhere - cannot come to their full potential without water, medication and electricity.

Socio-spatial autonomy constitutes a dimension of global inequalities structuring social positions much like resources do. The context does not refer only to territorial contexts and mobility in search of a better infrastructure. More often, context relations are political and social in nature, which makes them open to symbolic struggle and political closure. Nation states do not only protect a territorial border, they also include specific persons as citizens - even when these persons live abroad (Brubaker, 1992) and they exclude non-citizens - even when these non-citizens have lived on a state's territory for a long time. ${ }^{3}$ So an ethnic minority may be excluded from a nation state's protection even though they never moved. And if the physician from Aleppo reaches Germany, she may still not be able to fulfill her potential, because national professional law prohibits her from working as a doctor.

\footnotetext{
${ }^{3}$ Racial hierarchies serve a similar function as global systems of exclusion (Boatcă, 2015).
} 
In addition to political closure, the functionality of resources depends on context relations (Weiß, 2016). The manager of an agricultural firm may do well in a peripheral country but find it difficult to translate his skill set to a heavily industrialized context. Socio-spatial autonomy therefore is not to be equated with geographical movement alone. A high degree of sociospatial autonomy results from the ability to physically change contexts, from politically achieving a protected citizen status and from the versatility of the capital portfolio a person holds (Weiß, 2017).

Both the capability approach and the concept of socio-spatial autonomy are situated in the economic domain. So, at first glance, they seem to deal with a matter very different from refugee studies. Both literatures are however concerned with the complex relation between geographical movement and life chances. Erdal and Oeppen (2018) argue for refugees, that a person "forced" to stay in a good situation at home may have no option to choose, but will still be better off than a person who "chooses" to flee "voluntarily" along a life-threatening trajectory.

So, starting from a very general framework might lead us to a second step, in which the difference between refugees and migrants is specified within the general framework. In the Geneva Refugee Convention, a refugee is defined as a person who has a:

well-founded fear of being persecuted for reasons of race, religion, nationality, membership of a particular social group or political opinion, is outside the country of his nationality and is unable or, owing to such fear, is unwilling to avail himself of the protection of that country" (Article 1A(2), 1951 Refugee Convention). ${ }^{4}$

Clearly, the convention is not just about "force" or a lack of options. Neither is violence as such enough to claim asylum. Instead, the Geneva Refugee Convention focuses on two very specific aspects in which sociospatial autonomy may be compromised: Refugees are both territorially

$4<$ http://www.unhcr.org/protection/basic/3b66c2aa10/convention-protocol-relating-statusrefugees.html $>$. 
outside the provisions of their home state and politically disconnected from their nation-state.

There are further insights that a general migration theory can offer to the study of refugees and other migrants under duress. Even though refugees' socio-spatial autonomy is drastically compromised, they are still human beings, which means that they search for capabilities and they try to (re-)gain access. If the refugee situation is protracted, migrants under duress may want to take on a new citizenship and they will need social contexts in which their resources are validated. While the concepts of "refugee" and the literatures on forced or crisis migration focus on the legal preconditions of refugee status, on the moment of displacement and on populations in need of support, migration sociology would be more interested in how "becoming" a refugee is part of a longer-term buildup to a tipping point and how seeking refuge is a lengthy and stepwise process (Paul, 2011). ${ }^{5}$

In a more general migration sociological framework, processes of seeking refuge are imbedded in institutional frameworks structuring the lifecourse besides and beyond migration and refugee regulation. Schittenhelm (2005) and Nohl et al. (2014) have argued that life-courses can be studied as multi-dimensional status passages. Migrants and non-migrants alike pass through the educational system and try to enter labor markets. Irrespective of migration, people are secondly embedded in social relations, so that the labor market integration may overlap with the transition to marriage or parenthood. It is only in a third dimension of institutional embeddedness that migrants differ from sedentary populations: they cross national borders (Tsianos; Karakayali, 2010) and traverse mobility regimes (Schwarz, 2018). In the case of migrants, the first two dimensions of status passages also interact with a transition between nationally framed institutions (Nohl et al., 2014). This is the case, for example, when an undocumented migrant

${ }^{5}$ This is in line with recent literature in refugee studies such as Crawley and Skleparis (2018) who criticize the political implications of calling Syrians moving on to the EU after having tried to find protection in Turkey "transit migrants". 
regularizes her status by marrying a native. This gives her access to a visa category in which she can make partial use of her education as a doctor and enter the labor market as a nurse.

As a legal provision, the Refugee Convention is not concerned with broader context relations, but focuses on persecution and the need for protection. Rights to work, housing, education and so on are requested in chapters 3 and 4 , but the Convention also recognizes that access to these basic human rights may depend on the duration of time that refugees have spent in the country of asylum and on other factors. In practice, refugees are often kept in a "state of exception" for a long time (Koser; Martin, 2011; Agamben, 2014; Jansen, 2016). If they want to return to a normal life as soon as possible and want to work and/or study instead of waiting in a camp, publics in receiving countries do not see this as an attempt to overcome traumatic experiences, but as indicative of an abuse of refugee status (Sibum, 2010). ${ }^{6}$

The fact that refugees are also embedded in the labor market and social relationships is, of course recognized in the scholarship on refugees and crisis migrants, but mostly for very poor populations and exposed populations who are "forced" to work as part of reaching protection: "labour migration can become poorer households asylum migration, if the purpose of that migration is thought of as being broadly the security of the whole household, rather than more narrowly as a source of protection for an individual" (Van Hear, 2009, p. 15). Especially poor refugees find it hard to get protection and they must resort to labor migration in order to protect themselves and their relatives (Valenta; Jakobsen, 2017).

In a more general perspective, the relation between violent persecution, socio-economic resources and migration is probably more complex. Williams (2015) expands the mixed-migration approach on the basis of a representative survey and event history data of a civil war torn

${ }^{6}$ Until recently, Germany did not allow asylum applicants to study German or to work. Today, administrators distinguish between those who have a chance to stay and other applicants. The latter are still excluded from integration courses (Bach et al., 2017). 
valley in Nepal. The valley is characterized by a long history of emigration. Contrary to expectations, continued violence resulted in a decrease of emigration as compared to pre-conflict levels, as migration pathways became unsafe and people who would have emigrated prior to the conflict now tried to survive at home. So, in this case, violence resulted in a loss of socio-spatial autonomy, because in this valley socio-spatial autonomy largely took the form of territorial emigration. Williams (2015) also finds that the composition of emigrants changes during peaks of violence and thus proposes a "complex mixed-migration hypothesis", arguing that "not only do non-conflict related factors influence migration during armed conflict, but that the influence of such factors is different during a conflict compared to before it" (Williams, 2015, p. 45). In her view, the relationship between lack of protection and migration is "complex" since it is mediated by socio-economic conditions.

In sum, a life-course approach to migration contributes to our understanding of factors structuring the life-course of refugees that go beyond their legal status. Migrants differ from non-migrants in that their status passages are not only between education and labor market, and between being single and starting a family, but they also have to overcome national border regimes, a process during which they weigh the advantages and disadvantages diverse contexts offer in an effort to enhance - or in the case of refugees regain - socio-spatial autonomy. Refugees differ from most other migrants not only because they migrate under conditions of violence, but also because they lose territorial access to and political protection by their nation-state. Still as humans, refugees are also seeking better capabilities as part of long-term family, educational and career biographical trajectories.

Despite of the important legal differences between refugees and migrants, some continuities are to be expected. Violent persecution often goes hand in hand with a deterioration of other - more socio-economic - context factors (Williams, 2015, p. 46). The process of seeking refuge 
often is lengthy and happens through a series of step-wise migrations (Van Hear, 2009; Crawley; Skleparis, 2018), during which it may be difficult to distinguish between the trajectories of refugees and those of labor migrants (Toma; Castagnone, 2015; Kelly; Hedman, 2016). Finally, migrants under duress want to resume a life like everyone else - which incidentally is important for overcoming traumatization. Whether they do receive recognition and whether they can go on to find a new life, may depend on socio-economic factors as well as on the legal and political contexts that they enter.

\section{Sample and Methods}

In migration studies, sampling usually focuses on one or few ethnicities in one country of arrival. As migration is a stepwise process (Paul, 2011) governed by highly selective border regimes (Tsianos; Karakayali, 2010), it would be better to include countries of emigration, of transit and of arrival in surveys and to include all ethnicities. In recent years, more comprehensive samples encompassing several ethnicities in more than one country have been envisioned (Massey, 1987), but they remain an exception (Recchi; Favell, 2009; Crul et al., 2012; Wiesböck; Verwiebe, 2017).

Refugee studies also tend to focus on one or several countries of arrival, but in contrast to migration scholarship they pay more attention to countries of origin and migration trajectories (Schwarz, 2018). Due to the difficulty of reaching unprotected populations, representative samples are rare. ${ }^{7}$ Both researchers who apply the UNHCR definition of refugees and those who plead for a more comprehensive approach exclude from their sampling migrants who are not in need of support

${ }^{7} \mathrm{~A}$ new panel of all asylum claimants in Germany studies not only their migration trajectories and values, but also their educational and vocational characteristics which will enable comparison to non-refugee migrants (Brücker et al., 2016). Still the panel focuses on integration in one state of arrival alone as in other kinds of migration and integration studies and it draws a clear line between asylum seekers and other migrants. 
and protection. This makes it difficult to understand continuities between forced and "voluntary" migration and to understand the process how migrants under duress gain access to and accept the label "refugee" (Lacroix, 2004).

In an attempt to better understand the ways in which migrants under duress search for protection and how the legal category of "refugee" becomes salient in their life courses, this article revisits a sample of about 200 narrative interviews stemming from several qualitative research projects $^{8}$ which the author has (co-)conducted or supervised since 2002. All of the projects focused on the ways in which academically trained migrants gain recognition for the resources they hold after moving to another country. Professions, gender, and legal status varied greatly, while younger migrants between 18 and 45 years of age were preferred in the sampling. This article does not present comprehensive findings for 200 interviews, but it uses this pool to strategically select cases of migrants under duress, in order to reach conclusions on the basis of theoretical sampling (Glaser; Strauss, 1967).

For exploring continuities between migrants and refugees, the structure of the larger sample is ideal, because it focuses on migrants with a reasonable degree of resources which, in theory, should give them some aspirations and options in life. At the same time, the larger sample includes around 20 migrants under duress. For many of them the threat of violence was one reason to migrate, but they had not always applied for asylum. This overlaps with cases of migrants holding a very bad legal status as undocumented immigrants and/or asylum seekers at the time of the interview or during longer periods of their migration history. In the entire sample many migrants were socially demoted, and in the cases analysed here social demotion

${ }^{\mathbf{8}}$ The largest pool of interviews stems from an international study group "Cultural Capital During Migration" funded by the VW-Foundation in the years 2005-2009" and headed by the author together with Arnd-Michael Nohl, Karin Schittenhelm and Oliver Schmidtke (Nohl et al., 2014). The interviews in Turkey were conducted and analyzed by Barbara Pusch (2010; 2011). I would also like to thank Samuel Mensah, Stella Müller and Ariana Kellmer for giving me access to interviews and analyses conducted by them in various contexts. 
mostly resulted from legal exclusion (Pajo, 2008). Thus, a core group of self-declared and/or legally accepted refugees can be compared with a larger sample of other migrants who share some characteristics with core cases and/or live in similar circumstances.

As discussed above, migration is a highly selective process and the refugee category is central and contested in migration governance. It is therefore helpful for this article that the larger pool of interviews does not only contain migrants interviewed in Germany, but also those interviewed in other countries, mostly Canada, Turkey and South Africa. Among the smaller numbers interviewed, in Turkey $(n=20)$ and South Africa $(n=4)$, some talked about not being able to make it to the EU or Canada or about returning in response to racism there. These cases serve as a contrast for migrants under duress who were able to reach Germany and Canada.

In order to show the value of a sociological approach to migration under duress, data should not focus on migration decisions alone, but on the entire biography of the migrant. The interviewing technique employed in the studies is narrative with semi-structured follow-up questions. The interviews start with the initial request to the migrants to tell their life-story in great detail. The follow up questions focus on themes which were relevant to the particular study and which interviewees did not cover in enough detail during their initial narration. In addition, data on the legal and institutional context of the migration were collected by means of expert interviews, by analysing relevant documents and statistical material. ${ }^{9}$

The cases discussed in this article are interpreted with the help of the documentary method (Bohnsack, 2008; Bohnsack et al., 2010; Nohl, 2013). The documentary interpretation of narrative interviews does not only reconstruct explicit aspects of the life-story as pointed out by the interviewees themselves. Interpretation also focuses on the implicit set

${ }^{9}$ For a comprehensive description of the legal situation in Canada, Turkey and Germany at the time, see Nohl et al. (2014, p. 101-121). 
of knowledge that shapes daily practices and is embedded in them. For example, a young migrant may describe his migration decision as voluntary, but we may learn from his account that his social group was persecuted and he himself had been attacked prior to his move abroad. The documentary method thus enables an analytic distinction between explicit self-theorizations and implicit knowledge that is reconstructed through a comparison of narrations. Both levels of analysis are validated and both contribute to the findings.

The case studies in this article are presented in two steps. In the next section, we will contrast two cases of asylum seekers in Germany. Both left their homes in response to persecution, but while one of them fled in a manner that converges with the expectations underlying the Geneva Convention and German administrative rules, the other case diverges in various ways from legal and administrative provisions. In the fourth part, migrants who could fall under the Convention, but who have (partially) refrained from claiming asylum are included in the comparison. They were found in Turkey and Canada. Among other things, the comparison shows that those with better resources and a higher degree of socio-spatial autonomy can, if well informed, find better options for reaching protection.

\section{The process of seeking refuge and the legal and administrative provisions for refugee protection}

When the Geneva Refugee Convention was adopted, in 1951, it responded to large scale political persecution during the second world war, and it was geographically and temporally limited to protecting people seeking refuge from events in Europe prior to 1951. The temporal and geographic restrictions were lifted by the protocol relating to the status of refugees in $1967,{ }^{10}$ but the underlying assumptions on how people become refugees have remained the same.

$10<$ http://www.unhcr.org/protection/basic/3b66c2aa10/convention-protocol-relating-statusrefugees.html> 
International refugee protection is complemented by national legal and administrative provisions. In Germany, for example, § 16a in the constitution asserts that politically persecuted individuals have a right to asylum. Up to the 1980s, the typical refugee in Germany was a dissident from communism who had crossed the border as part of an official delegation. When numbers rose and asylum seekers were not individual dissidents, but e.g. refugees from civil war torn Yugoslavia, an intense public debate ensued and in 1994 an amendment to the constitution was passed, ruling that persons entering from safe third countries can be returned to these countries and should ask for asylum there.

In our large sample, more than a dozen interviewees, mostly in Germany, explicitly identified themselves as refugees at the time of the interview or as part of their biographical narration. Looking at some of these cases more closely confirms a frequently voiced contention (Koser; Martin, 2011, 7), that the historical circumstances of the Geneva Convention as well as its administration in nation states may not conform with the empirical reality of many refugees today. Mr. Ibezim ${ }^{11}$ fits the archetypal image of a political refugee to which the German legislation is tailored, whereas Mr. Mammud represents the - more frequent refugees that diverge.

Mr. Ibezim was interviewed in 2006, three years after he had entered Germany. Sometime after the interview, he was officially recognized as a refugee. In his African home country Mr. Ibezim had been working in an economic sector that had received a lot of international criticism for harming the environment, killing critics and rampant corruption. Mr. Ibezim was trained by a German development agency wishing to support professionals in their endeavor to combat this kind of bad practice. A conference by that agency in Germany enabled him to enter Germany directly and legally via airplane and then go on and claim asylum after arrival.

11 Names and other details have been changed. In some cases, we felt it necessary to obscure the country of origin. 
During the short time he spent on German streets weighing his options, he met compatriots who encouraged him to claim a false nationality. They informed him that chances of acceptance are very low for their nationality, but he says in the interview that he preferred to stay with the truth. We cannot control the extent to which this account is truthful, but the way he portrays himself in the interview attests to the fact that he is skillful in handling suspicion by the migrant administration.

In all of these points, Mr. Ibezim conforms with the historic experience and expectations Germany has concerning asylum seekers: Much like political activists from Eastern Europe during the cold war, he entered Germany legally and then asked for asylum. These often famous activists received a high degree of respect for their upright stance and asylum was normally granted. This also means that Mr. Ibezim fits into an administrative loophole. As mentioned, the 1994 amendment to the constitution ruled that safe third countries should be responsible for processing refugees. Ever since, all neighboring countries have been deemed to be safe and Germany exterritorialized border controls to airplane companies in order to make sure that no one can enter an airplane to Germany without a proper visa. That Germany still had to process large number of asylum seekers resulted from them entering Germany illegally and/or "losing" their documents in the process. This ensured that Germany had to process their claims as it was unknown from which country they had entered or to which country they could be deported. This, of course, undermined the credibility of their claim.

Mr Ibezim is an exceptional case of a refugee who was able to legally enter Germany directly from his distant home country with a conference visa, despite of being under threat there. He also is an exception in that he can truthfully claim to conform to all legal regulations and in that he did indeed receive the protection he needs. We can therefore take his case as a test case for exploring our assertion that a life course approach might offer insights into the process of becoming a refugee. Taking a closer look at the interview we can find some indication that Mr Ibezim is not just concerned 
with persecution and legal matters. When describing the moment in which he left, he mentions that he had been married for a short time, but was otherwise without social relations, which made it easier for him to leave. Mr. Ibezim also details his professional achievements and desire to perform well in the labor market. After claiming asylum, he is amazed to learn that Germany does everything to deport him rather than seeing the contribution that he could make to the country. Both points confirm that even for a refugee conforming to international and German asylum law, to a high degree his personal life and his professional identity matter both for the decision to flee and for the way he positions himself in the receiving country.

For the majority of asylum applicants found in Germany, taking flight is a much more complicated and longer-term process (Brücker et al., 2016, p. 5). The case of Mr. Mammad is discussed in contrast to Mr. Ibezim, because he clearly flees from persecution, but he diverges from several provisions of the Geneva Convention and of German administrative regulations. Mr. Mammad comes from a country that formed after the dissolution of the Soviet Union. Soon afterwards 20 percent of her territory was lost:

we were supposed to leave our house and the entire family left just with the clothes we wore. We had a two storied private house and about a hectare of farm and we had to leave because the tanks came. (...) some people were ill and stayed (...) we lost everything all our documents and I had studied for five years in Ukraine (...) and that diploma was left there and we went through a river (...) and after about a kilometer you see that your house is already burning our house already burned that was very difficult in front of your eyes this happened that is psychologically and everything this I have about forty years of age, my hair is all white.

Mr. Mammad's account is vivid and it becomes clear that leaving was a matter of life and death. In comparison to Mr Ibezim, his future options appear much more limited, because he loses both his diploma and, as it later turns out, his employability in the course of the flight. Whether he can contribute to the prosperity of the receiving country is not a consideration he is having in mind. 
At this time, we might view Mr. Mammad to be a displaced person, but he does not (yet) conform with the legal definition of refugee because he flees to a camp in the newly founded republic. In the camp he and others realize soon that they are not treated well by their "own" new country. They protest and after Mr Mammad witnesses police violence against another protester, he and his family flee again. At this point $\mathrm{Mr}$ Mammad takes a more conscious decision. Since he suspects that Russia might turn him back, his main objective is reaching any democratic country. The way in which he reached Germany is not elaborated upon, but hints suggest the then prevailing path, i.e. illegal entry with the help of smugglers. At the time of the interview, his case was still processed. Since both of his children are chronically ill, he is likely to receive humanitarian protection.

From the perspective of refugee protection, Mr Mammad's case is dubious in several respects: The first violent displacement can be seen as "internal" to a new state. His second move could be contested as "voluntary", because he also might have stayed in a camp in "his" country. From the perspective of Germany, his case could also be processed in a safe third country and he undermines the German regime by obscuring the path he took. Finally, the protection he is likely to receive depends more on the bad health of his children, than on the fact of the violent persecution and lack of protection that turned the family into refugees.

Both cases shed some light on the consecutive "decisions" refugees take in an attempt to lead their lives and to choose the best of bad options. Mostly, they show that the complexity of seeking refuge is not sufficiently grasped by legal and administrative provisions which turns refugees like Mr Mammad into asylum applicants that were ready to resort to semi-legal avenues. We may conclude that the attribution of refugee status does not depend on legal matters alone, but also on other factors. The latter can best be explored with the help of a broader sample and a more general migration theory. 


\section{Resource endowment and the ability or need to claim refugee status}

After having confirmed that legal and administrative definitions of refugee status may diverge from the empirical patterns of seeking refuge, we will now take a closer look at contrasting cases found in other destination countries. This enables us to better understand the selectivity of migration and the socio-economic inequalities that result in migration trajectories conforming and not conforming to the Geneva Convention. It also explains why some migrants do not see themselves as refugees even though their migration responded to violence and a lack of protection in their home country.

In contrast to the cases discussed above, who did reach Germany, Mr. Young was interviewed in Turkey, in 2005, where he had remained for fifteen years despite of continuous attempts at onward migration to Europe. ${ }^{12}$ Before entering Turkey, he had studied law and international relations in the Soviet Union with the help of a scholarship awarded by his home country, Rwanda. In 1991, when he was about to conclude his studies, that "was a time when civil war in Rwanda was very, very dangerous. There was no way on getting back when I was finishing my university". His country called him home so that he could join the army. When he refused to do so, his scholarship was discontinued. Without payment, the Russian university at which he studied did not let him take his final exam.

In this situation he visited several consulates in Moscow in a vain attempt to get a student visa for any West European country. He then moved to Turkey in the hope of an illegal border crossing to the EU at which he failed, too. West European consulates again turned down his application which resulted in him assuming the life of undocumented and illegal migrants stranded in Turkey. He starts to work and, since he is highly visible as a black man, he is arrested again and again, but always released after a short

${ }^{12} \mathrm{Mr}$ Young was interviewed in English, a second language to him and the interviewer, Barbara Pusch. For a discussion of the situation of refugees in Turkey see Pusch (2010). 
time and starts to work again. After two years, the political climate changes for the worse and he is deported to a camp in the East of Turkey which he barely survives. After managing a successful escape back to Istanbul, he is imprisoned two more times. At the time of the interview he had spent 15 years in Turkey unable to move on.

Assuming a legal perspective and considering that Mr. Young was actually studying law and international relations at the time, we would have expected him to apply for asylum. Given that a genocide was happening in Rwanda-which he euphemistically calls "civil war" —and that he was called back to join the army, he must have felt the well-founded fear of persecution and lack of protection the Refugee Convention calls for. But in his introductory narration he is concerned about continuing his studies. "And then I felt I could be lucky to go to Europe and then finish there university, finish my degree". It is only later that Mr. Young tries to officially claim refugee status.

Looking at Mr. Young's biographical perspective the reluctance to claim asylum can be easily explained. At the moment he turns into a refugee, he still sees himself as a student. Having almost concluded an academic education he is rich in cultural capital. Even though he would see himself as lucky to go to Europe, it is not unreasonable for him to try to continue his academic education there. At the same time, acceptance as an asylum seeker would not have improved his lot. Until recently, Turkey did not accept refugees from non-European origins and registered refugees were not legally allowed to work. UNHCR registered refugees to Turkey, but UNHCR's main offer was resettlement to another country after long waiting periods (Pusch, 2011). So, claiming asylum status would not have helped Mr. Young to continue his studies. He therefore first tries to get a student visa, then to reach Europe illegally, which would have put him in about the same position that we have found in Mr. Mammad and only as a final resort does he register with UNHCR. 
Mr. Young is not the only migrant under duress who refrains from claiming refugee status. Ms. Goudareva ${ }^{13}$ was interviewed in 2005, too, but in contrast to Mr. Young she has reached Canada with the help of the Canadian point system. Coming from civil war torn Chechnya her narration is similar to that of refugees, but she never identifies herself as such:

Ok, I am from the south of Russia and when everything started in Chechnya I started to wonder what am I gonna do... ahm... By education I am a chemical engineer-I have Master's .... and I used to work on military plant for seven years. Then in $1991 \ldots$... '90 ... yes, '91 ... government started to cut all financing and we had less and less contracts and it became dangerous in country. (...) I then started my own business. (...) And in 1998 just many things happened at once: I got divorced; everything just crashed in the country and ... ah... six or seven people from my very close ... ahm ... friends and family died in very different situations. Two were killed, one had a heart attack you know, just and I seriously started to think about immigration. I applied and it was only two countries available: New Zealand and Canada for professional immigration. I don't have relatives abroad and I chose Canada. Because it is closer in climate and it's better it is far away.

In many respects, Ms. Goudareva's account compares to that of those claiming asylum in Germany or Turkey. She never considered emigration before the political situation in Chechnya and her personal life deteriorated dramatically. Then, she simply wants to leave, that is, she does not have a specific destination in mind but only researches what her legal destination options are.

After this point, the accounts start to diverge drastically. In contrast to Mr. Young (but like Mr. Mammad and Mr. Ibezim) she holds an academic degree. In contrast to all others she has the time and financial resources to apply for professional immigration-which includes travelling to Paris, where she must pass an interview. She is able to gain access as a professional migrant to Canada, even though she is relatively old, and knows very little English and no French. It seems that the decisive difference between Ms. Goudareva and the others is that she is privileged in her financial resources

\footnotetext{
${ }^{13}$ Ms. Goudareva was interviewed in English by Oliver Schmidtke and Beatrice Marry.
} 
and that she has the ability and time to gather not word of mouth, but reliable information about legal alternatives to claiming asylum. ${ }^{14}$

Besides money and the time and ability to search for information, we can also suspect that racism plays a role in structuring migrants' options. This becomes apparent by a contrast between Mr. Young and Mr. Fagan, ${ }^{15}$ a white South African who entered Canada with the help of the point system. Asked when the idea of leaving his country first crossed his mind Mr. Fagan responds:

Um, it had been in the back of my mind because my brother had left and my sister had left, and it was a place where there was so much nastiness and even by virtue, like even if you weren't a racist, because of the changes, if you weren't African, people, who were perhaps abused years ago, didn't stop to check if you were a nice white guy or not, they just had this animosity $/ / \mathrm{mmh} / /$ I got mugged and stabbed and that was sort of the end of it [...] Well, it wasn't really the end of it because I went out the next day and bought my wife and I each a gun so we spent a few months walking around packing guns thinking that we, eventually we thought, "This is bull shit" [...] And my brother was in Calgary saying how nice it was [...] So eventually we decided to give it a go.

At first sight, Mr. Fagan conforms at least as well to the category of refugee as the other cases discussed in this article. He has survived a direct attack on his life. Like the others he experiences a general deterioration for his ethnic group prior to the last straw which makes him leave. Later in the interview we learn that he employs a trial-and-error semi-legal migration strategy much like many refugees.

Despite of these similarities Mr. Fagan never describes himself as a refugee nor does he claim asylum. This is in line with a legal view arguing that his native state, South Africa, does in fact try to protect all citizens, including whites, from violence. It also corresponds to his subjective biographical

${ }^{14}$ The opposite is the case for another interviewee in Germany. Mr. Ahmad from Pakistan had the bad luck of not only being an IT-professional, but also a political activist. As he was politically persecuted he applied for asylum and ended up in a dead-end street, when he could have gained a green card for IT-professionals had he been better informed.

${ }^{15} \mathrm{Mr}$. Fagan was interviewed in English by Oliver Schmidtke and Beatrice Marry. 
perspective according to which he was young, wanted to break away from the family business and follow his brother in an attempt to explore the world. This said, reconstructive analysis shows that he had a well-founded fear of group-based violence. At the time of his emigration, apartheid had just ended and it was unclear whether white South-Africans would eventually be disowned as in neighbouring Zimbabwe or continue to receive protection by their state. In addition, he actually did become a target for violence based on race. The fact that Mr. Fagan was willing to give up a position in which he managed 300 workers, in order to work illegally in the UK and as a sales person in Canada, may be explained as youthful exploration, but it could also support the view that he migrated under some degree of duress. We therefore conclude that this is a counter-intuitive case of a forced migrant who does not see himself as such.

That this is so, again points to the larger inequalities structuring whether migrants become refugees or not. In contrast to the black Rwandan Mr. Young, who is unable to get a EU visa to continue his studies, the white South African Mr. Fagan has no trouble to migrate to Great Britain and work there illegally:

When I initially applied in South Africa through the Canadian High Commission, they said there's a four- or five-year wait list to even be processed so we'll get back to you [laughs]. So then I left South Africa and went to England and I applied from England to immigrate to Canada and to Belgium so within five months, my Canadian application came through, and, um, since it was the first one I took that and we got here in '95 after living in England for about a year and a half. My wife was on a youth work permit, so she was working legally, I was working illegally, just getting by.

In legal terms, Mr. Fagan never is a refugee. Neither has he reason to see himself as seeking refuge. He belongs to the category of people who are well endowed with resources and who can therefore afford to use other migration channels even when they are compelled to leave. His socio-spatial autonomy is not restrained by his passport nor by racism. 
After establishing that asylum law and administration often run counter to the realities of seeking refuge, this sub-chapter discussed several migrants who left under duress but neither saw themselves as refugees nor did they claim asylum. That they were avoiding refugee status does not only follow from the relatively high amount of resources some of them held. It also signifies different patterns of socio-spatial autonomy. As well-informed white professionals Ms. Goundareva and Mr. Fagan can access the Canadian system of high skilled immigration and they do not even mention the option of seeking refuge. In contrast to them, Mr. Young had to learn the hard way that the refugee status is the only option available for a black man without a formal university certificate, who was unable to illegally cross the Mediterranean.

\section{Conclusion}

Whether a migrant under duress is a refugee, is highly contested: in law, in administrative practice, in public discourse and in the empirical social sciences. Researchers who explore continuities between refugees and other migrants can unwillingly contribute to a further deterioration of refugee protection. The opposite could also be the case, if gaps between the empirical reality of seeking refuge and the legal preconditions of gaining protection existed: Political and public commentators see these gaps and exploit them to discredit refugees (Crawley; Skleparis, 2018; Erdal; Oeppen, 2018).

Against this background, in this article I argue that a broader migration approach can contribute to understanding the ways in which the refugee category is used and appropriated by administrations, but also by refugees themselves. We use a large multi-country sample of migrants holding academic degrees to contextualize cases of migrants under duress, i.e. migrants who experienced violent persecution and lack of protection, but who did not always apply for refugee status nor did they always receive it.

Findings confirm that the experience of violent persecution and lack of protection are just one factor, which in itself is not decisive for whether 
a person becomes a refugee in legal terms. In fact, cases from Germany show that legal and administrative provisions result in a majority of refugees being excluded from reaching the country and only a minority of those reaching Germany in need of protection being protected as refugees. ${ }^{16} \mathrm{Mr}$. Mammad was discussed exemplarily for the majority of asylum seekers who likely used clandestine means to enter Germany and who is unlikely to receive protection as a refugee. In contrast to legal provisions focusing on a "state" of being persecuted and unprotected, seeking refuge was a step-wise process for Mr. Mammad and it is difficult to establish which state should be responsible for him. In Germany, redefinitions of the refugee category serve to reduce the number of legal asylum recognitions and they are used to undermine refugees' credibility.

Against this background, the study applied a broader migration sociological approach to contextualize cases of migrants under duress. In this framework, seeking refuge is embedded in a life course, during which people who need protection as refugees also pursue other goals. This was shown for Mr. Ibezim who clearly is a refugee, in legal and sociological terms, and in his self-description. In other case studies, the preconditions of becoming a refugee became more apparent. Looking at cases of migrants under duress who did not or could not successfully claim asylum, I showed that (self-)ascription of the refugee category and finding a safe haven also depend on the resources a person holds and on their socio-spatial autonomy.

In terms of resources, valid information and time to weigh options, as well as money and academic degrees, enable migrants under duress to not even consider an asylum application. Another factor was termed socio-spatial autonomy, i.e. the ability to remain in a well-equipped context or search for a better one. Refugees' are territorially and politically disconnected from the state of their nationality, but they may additionally suffer other constraints of

${ }^{16}$ The protection rate varies. Summing up several years, more than a third of applicants are refused. Among those who do receive some kind of protection, other legal attributes are frequent, so that only a minority receives recognition as refugee (Bundesamt Für Migration Und Flüchtlinge, 2018, 50). 
socio-spatial autonomy. As a black Rwandan Mr. Young found it impossible to enter the EU even illegally, whereas the white South African Mr. Fagan mentions on the side that he spent some time working illegally in the UK prior to gaining a Canadian visa. This points to the possible relevance of racial stratification for finding protection.

Due to the small number of cases, a systematic analysis of all the institutions, resources and context relations that impact on the process of becoming a refugee could not be achieved in this study. It did however supply empirical support for the contention, that the life-course of refugees and the preconditions for achieving refugee status deserve more attention, if we want to understand who "becomes" a refugee. While it may be vital for the destitute to reach refugee status, the more well-endowed may have good reasons to shy away from it. Among those who migrate under duress, the ways and extent to which they can achieve protection, resume a normal life and expand their capabilities are not bifurcated along the lines of being a refugee or not. Rather, options are structured by global inequalities, i.e., they are drastically unequal, depending on the resources a migrant holds, but also on country of origin, racial status, and mere chance.

Allowing for a partial overlap between refugees and migration also enables to see refugees not only as passive victims but also as agents who want to resume "leading a life". Further research should build on the literatures asserting an "autonomy of migration" (Papadopoulos; Tsianos, 2013; Schwarz, 2018) or exploring the subjective experience of "refugeeness" (Jackson; Bauder, 2014) in that respect. That refugees also lead lives, should not be discredited as "free volition", but seen as one way of overcoming the effects of violent persecution.

Anja Weiß is a professor of the Institute of Sociology at the Duisburg-Essen University, Germany.

$\Xi$ anja.weiss@uni-due.de 


\section{References}

1. AGAMBEN, Giorgio. Die Souveränität der Macht und das nackte Leben. Frankfurt: Suhrkamp, 2014.

2. BACH, Stefan et al. Investitionen in die Integration der Flüchtlinge lohnen sich. DIW Wochenbericht, v. 84, n. 3, p. 47-58, 2017.

3. BALDWIN-EDWARDS, Martin; BLITZ, Brad K.; CRAWLEY, Heaven. The politics of evidence-based policy in Europe's "migration crisis". Journal of Ethnic and Migration Studies, p. 1-17, 2018. Available at: < https://doi.org/10.1080/13 69183X.2018.1468307>.

4. BOATCĂ, Manuela. Global inequalities beyond occidentalism. Aldershot: Ashgate, 2015.

5. BOHNSACK, Ralf. Rekonstruktive Sozialforschung: Einführung in qualitative Methoden. 8. ed. Opladen: Barbara Budrich, 2008.

6. BOHNSACK, Ralf.; PFAFF, Nicole; WELLER, Wivian (Eds.). Qualitative analysis and documentary method in international educational research. Opladen: Barbara Budrich, 2010.

7. BOURDIEU, Pierre; CHAMBOREDON, Jean-Claude; PASSERON, Jean-Claude. Soziologie als Beruf. Wissenschaftstheoretische Voraussetzungen soziologischer Erkenntnis. Berlin: De Gruyter, 1991.

8. BRUBAKER, Rogers. Citizenship and nationhood in France and Germany. Cambridge: Harvard University Press, 1992.

9. BRÜCKER, Herbert et al. IAB-BAMF-SOEP-Befragung von Geflüchteten: Flucht, Ankunft in Deutschland und erste Schritte der Integration. IAB-Kurzbericht, n. 24, p. 2016. Available at: <http://doku.iab.de/kurzber/2016/kb2416.pdf>.

10. BUNDESAMT FÜR MIGRATION UND FLÜCHTLINGE. Das Bundesamt in Zahlen 2017. Asyl, Migration und Integration. Nürnberg: Bundesamt für Migration und Flüchtlinge, 2018. Available at: < http://www.bamf.de/SharedDocs/ Anlagen/DE/Publikationen/Broschueren/bundesamt-in-zahlen-2017.pdf? blob= publicationFile $>$.

11. CASTLES, Stephen. The factors that make and unmake migration policies. In: PORTES, Alejandro; DEWIND, Josh (Ed.). Rethinking migration: new theoretical and empirical perspectives. New York: Berghahn Books, 2007. p. 29-61.

12. CASTLES, Stephen. Migration policies are problematic - because they are about migration. Ethnic and Racial Studies, v. 40, n. 9, p. 1538-43, 15 jul. 2017. Available at: <https://doi.org/10.1080/01419870.2017.1308532>.

13. CRAWLEY, Heaven; SKLEPARIS, Dimitris. Refugees, migrants, neither, both: categorical fetishism and the politics of bounding in Europe's "migration crisis". Journal of Ethnic and Migration Studies, v. 44, n. 1, p. 48-64, 2 jan. 2018. Available at: <https://doi.org/10.1080/1369183X.2017.1348224>. 
14. CRUL, Maurice; SCHNEIDER, Jens; LELIE, Frans. The European Second Generation Compared: Does the Integration Context Matter? Amsterdam: Amsterdam University Press, 2012.

15. DAHINDEN, Janine. A plea for the 'de-migranticization' of research on migration and integration. Ethnic and Racial Studies, p. 1-19, 2016. Available at: < http://dx.doi.org/10.1080/01419870.2015.1124129>.

16. ERDAL, Marta Bivand; OEPPEN, Ceri. Forced to leave? The discursive and analytical significance of describing migration as forced and voluntary. Journal of Ethnic and Migration Studies, v. 44, n. 6, p. 981-98, 26 abr. 2018. Available at: < https://doi.org/10.1080/1369183X.2017.1384149>.

17. FELLER, Erika. Refugees are not migrants. Refugee Survey Quarterly, v. 24, n. 4, p. 27-35, 2005. Available at: <http://dx.doi.org/10.1093/rsq/hdi077>.

18. FIDDIAN-QASMIYEH, Elena; LOESCHER, Gil; LONG, Katy; SIGONA, Nando. The Oxford handbook of refugee and forced migration studies. Oxford: Oxford University Press, 2014.

19. FITZGERALD, David Scott; ARAR, Rawan. The sociology of refugee migration. Annual Review of Sociology, v. 44, n. 1, p. 387-406, 2018. Available at: < https:// www.annualreviews.org/doi/abs/10.1146/annurev-soc-073117-041204>.

20. GLASER, Barney; STRAUSS, Anselm L. The discovery of grounded theory: strategies for qualitative research. Chicago: Aldine, 1967.

21. HOLLIFIELD, James F. Migration and the "new" international order: the missing regime. In: GHOSH, Bimal (Ed.). Managing migration: time for a new international regime. Oxford: Oxford University Press, 2000. p. 95-109.

22. JACKSON, Samantha; BAUDER, Harald. Neither temporary, nor permanent: the precarious employment experiences of refugee claimants in Canada. Journal of Refugee Studies, v. 27, n. 3, p. 360-81, set. 2014. Available at: <<Go to ISI > :/WOS:000342981700003>.

23. JANSEN, Bram J. "Digging aid": the camp as an option in East and the Horn of Africa. Journal of Refugee Studies, v. 29, n. 2, p. 149-65, 2016. Available at: <http://dx.doi.org/10.1093/jrs/fev018>.

24. KELLY, Melissa; HEDMAN, Lina. Between opportunity and constraint: understanding the onward migration of highly educated Iranian refugees from Sweden. Journal of International Migration and Integration, v. 17, n. 3, p. 64967, 2016. Available at: <http://dx.doi.org/10.1007/s12134-015-0422-4>.

25. KOSER, Khalid; MARTIN, Susan. The migration-displacement nexus. In: KOSER, K.; MARTIN, S. (Eds.). The migration-displacement nexus: Patterns, Processes and Policies. New York: Berghahn Books, 2011. p. 1-13.

26. LACROIX, Marie. Canadian refugee policy and the social construction of the refugee claimant subjectivity: understanding refugeeness. Journal of Refugee Studies, v. 17, n. 2, p. 147-66, 2004. Available at: <http://dx.doi.org/10.1093/ jrs/17.2.147>. 
27. LAUBE, Lena; MÜLLER, Andreas. Warum die Kontrolle abgeben? Die Delegation von Migrationskontrolle aus der Prinzipal-Agent-Perspektive. Berliner Journal für Soziologie, v. 25, n. 3, p. 255-81, out. 2015. Available at: <<Go to ISI>://WOS:000371242200002>.

28. MASSEY, Douglas S. The ethnosurvey in theory and practice. The International Migration Review, v. 21, n. 4, p. 1498-522, 1987.

29. MCADAM, Jane. Conceptualizing "crisis migration": a theoretical perspective. In: MARTIN, Susan F.;WEERASINGHE, Sanjula; TAYLOR, Abbie (Eds.). Humanitarian crises and migration: causes, consequences and responses. New York: Routledge, 2014. p. 28-49.

30. MONEY, Jeannette; LOCKHART, Sarah P. The paucity of international protections: global migration governance in the contemporary era. Global Summitry, v. 3, n. 1, p. 45-67, 2017. Available at: <http://dx.doi.org/10.1093/ global/guy007>.

31. NIESWAND, Boris. Die Dezentrierung der Migrationsforschung. In: KAZZAZI, Kerstin; TREIBER, Angela; WÄTZOLD, Tim (Eds.). Migration - Religion - Identität. Aspekte transkultureller Prozesse. Wiesbaden: Springer VS, 2016. p. 283-297.

32. NOHL, Arnd-Michael. Interview und dokumentarische Methode. Anleitungen für die Forschungspraxis. 4. ed. rev. Wiesbaden: VS Verlag, 2013.

33. NOHL, Arnd-Michael et al. Work in transition. Cultural capital and highly skilled migrants' passages into the labour market. Toronto: Toronto University Press, 2014.

34. PAJO, E. International migration, social demotion, and imagined advancement: an ethnography of socioglobal mobility. 2. ed. New York: Springer, 2008.

35. PAPADOPOULOS, Dimitris; TSIANOS, Vassilis. After citizenship: autonomy of migration, organisational ontology and mobile commons. Citizenship Studies, v. 17, n. 2, p. 178-96, 2013.

36. PAUL, Anju Mary. Stepwise international migration: a multistage migration pattern for the aspiring migrant American Journal of Sociology, v. 116, n. 6, p. 1842-86, 2011.

37. PUSCH, Barbara. Vom Tellerwäscher zum Millionär? Arbeitsmarktpartizipation von Ausländerlnnen in der Türkei. IMIS-Beiträge, v. 36, p. 119-38, 2010.

38. PUSCH, Barbara. Irreguläre Migration in die Türkei. Facetten, Zahlen und Tendenzen. In: PUSCH, Barbara; TEKIN, Uğur (Eds.). Migration und Türkei. Neue Bewegungen am Rande der Europäischen Union. Würzburg: Ergon und Orient-Institut Istanbul, 2011. p. 153-70.

39. RECCHI, Ettori; FAVELL, Adrian (Eds.). Pioneers of European integration: citizenship and mobility in the EU. Cheltenham: Edward Elgared. 2009. 
40. ROBERTSON, Shanthi. Status-making: Rethinking migrant categorization. Journal of Sociology, online first, 13 ago. 2018. Available at: < http://journals. sagepub.com/doi/abs/10.1177/1440783318791761>.

41. SCHITTENHELM, Karin. Soziale Lagen im Übergang. Junge Migrantinnen und Einheimische zwischen Schule und Berufsausbildung. Wiesbaden: VS Verlag für Sozialwissenschaften, 2005.

42. SCHWARZ, Inga. Migrants moving through mobility regimes: the trajectory approach as a tool to reveal migratory processes. Geoforum, 16 mar. 2018. Available at: < http://www.sciencedirect.com/science/article/pii/S0016718518300848>.

43. SEN, Amartya. Commodities and capabilities. Nova York: North-Holland, 1985.

44. SIBUM, Helen. "Asylshopping" und "Flüchtlingswellen" - ein Vergleich des Migrationsdiskurses in Deutschland und Australien. Berlin: Logos-Verl., 2010.

45. STEPPUTAT, Finn; SØRENSEN, Nina N. Sociology and forced migration. In: FIDDIAN-QASMIYEH, Elena et al. (Eds.). The Oxford handbook of refugee and forced migration studies. Oxford: Oxford University Press, 2014. p. 86-98.

46. TOMA, Sorana; CASTAGNONE, Eleonora. What drives onward mobility within Europe? The Case of Senegalese migrations between France, Italy and Spain. Population, v. 70, n. 1, p. 69-101, 2015. Available at: <<Go to ISI $>$ :// WOS:000357141200004>.

47. TSIANOS, Vassilis.; KARAKAYALI, Serhat. Transnational migration and the emergence of the European border regime: an ethnographic analysis. European Journal of Social Theory, v. 13, n. 3, p. 373-87, 2010.

48. VALENTA, Marko; JAKOBSEN, Jo. Mixed migrations to the Gulf: an empirical analysis of migrations from unstable and refugee-producing countries to the GCC, 1960-2015. Refugee Survey Quarterly, v. 36, n. 2, p. 33-56, jun. 2017. Available at: << Go to ISI > ://WOS:000404131600002>.

49. VAN HEAR, Nicholas. Managing mobility for human development. The growing salience of mixed migration. Human Development Research Paper, 2009/20. United Nations Development Programme, 2009. Available at: <http:// hdr.undp.org/sites/default/files/hdrp_2009_20.pdf >.

50. VAN HEAR, Nicholas. Forcing the issue: migration crises and the uneasy dialogue between refugee research and policy. Journal of Refugee Studies, v. 25, n. 1, p. 2-24, mar. 2012. Available at: <<Go to ISI > :/WOS:000301363200002>.

51. WEIß, Anja. Understanding physicians' professional knowledge and practice in research on skilled migration. Ethnicity \& Health, v. 21, n. 4, p. 397-409, 2016.

52. WEIß, Anja. Soziologie globaler Ungleichheiten. Berlin: Suhrkamp, 2017.

53. WEIß, Anja. Contextualizing global inequalities. A sociological approach. In: KORZENIEWICZ, Roberto P. (Ed.). The World-System as unit of analysis: past contributions and future advances. New York: Routledge, 2018. p. 75-85. 
54. WIESBÖCK, Laura; VERWIEBE, Roland. Crossing the border for a higher status? Occupational mobility of East-West commuters in the Central European Region. International Journal of Sociology, v. 47, n. 3, p. 1-20, 2017.

55. WILLIAMS, Nathalie E. Mixed and complex mixed migration during armed conflict: multidimensional empirical evidence from Nepal. International Journal of Sociology, v. 45, n. 1, p. 44-63, 2015. Available at: << Go to ISI > :// WOS:000217700100004>.

56. ZETTER, Roger. Protection in crisis: forced migration in a global era. Washington: Migration Policy Institute, 2015. Available at: < http://www. migrationpolicy.org/research/protection-crisis-forced-migrationand-protectionglobal-era $>$. 